\title{
Mites of the genus Calcarmyobia (Acarina, Myobiidae) with information on the taxonomy of their host bats of the genus Miniopterus (Chiroptera, Miniopteridae)*
}

\section{Kimito Uchikawa}

Department of Parasitology, Shinshu University School of Medicine, Matsumoto 390, Japan

\section{Introduction}

The tendency to regard the genus Calcarmyobia Radford as monotypic was prevalent until the beginning of the 1970s. The eight known species of the genus have been described on strict definition of each species (Uchikawa, 1982), and it is gradually proved that the mites of the genus Calcarmyobia are specific parasites of bats of the genus Miniopterus. Referring to the present knowledge of the mites, such formerly proposed specific names Calcarmyobia miniopteris and $C$. parenzani for species from South Africa and Europe, respectively, as well as some host records, should be revised (Uchikawa, 1984).

Mites of the genus Calcarmyobia have been evaluated as good indicators in the taxonomy and phylogeny of their host bats (Uchikawa \& Harada, 1981). As the taxonomy of Miniopterus is not in a satisfactory state, an accumulation of records of the mites is believed to give a clue for solving some complicated problems in this area.

The present author had an opportunity to examine for ectoparasites the bat specimens deposited in the collections of the big museums in Europe and the United States. The present paper presents the records of the five species of the genus Calcarmyobia taken during the trip to add to the knowledge of the mites themselves and their host taxonomy.

The abbreviations for the museums, where the material dealt with in the present paper was collected, are as follows: AMNH-American Museum of Natural History, New York; BMNH-British Museum (Natural History), London; BSPM-Bernice P. Bishop Museum, Honolulu; FMNH - Field Museum of Natural History, Chicago; MNHN-Museum National d'Historie Naturelle, Paris; RMNH-Rijksmuseum van Natuurlijke Histoire, Leiden; SMF-Forschungs-Institut Senkenberg, Frankfurt.

\section{Records of mites}

\section{Calcarmyobia rhinolophia (Radford, 1940)}

Myobia rhinolophia Radford, 1940, Parasitol., 32: 91.

Calcarmyobia rhinolophia (Radford, 1940), Radford, 1952, Bull. Mus. Hist. Nat., Paris., 24: 371; Fain, 1978, Ann. Mus.r. Afr. cent., (Sci. Zool.), 224: 92; Uchikawa, 1982, Annot. zool. Japon., 55: 32.

This species was described originally on the material taken from a number of bats by G. H. E. Hopkins and T. H. E. Jackson in a cave at Kapretwa, Mt Elgon, Kenya (Radford, 1940). The host was given as 'a bat (Rhinolophus lobatus Peters)', but any bat of the genus Rhinolophus is not a true host of Calcarmyobia. With the guidance of Mr John Edwards Hill, Mammal Section, British Museum (Natural History), the present author located 2 series of bat specimens collected by Hopkins and Jackson at Kapretwa in 1938 and 1940. As Radford's manuscript dealing with Myobia rhinolophia was received for publication on 31 October 1939, the mites had presumably been obtained from the bats caught in 1938. The bats labelled M. natalensis arenarius with BMNH 1938.5.10.10-14 and 1938.5.10.4-9 for Rhinolophus lobatus yielded a male (1984.6.12.11)

*Supported financially by Overseas Scientific Research Grant Nos. 57041019 and 5803013 from the Ministry of Education, Science and Culture, Japan. Contribution No. Ac-2. 
and 2 females (1984.6.12.10) of C. rhinolophia. Thus, a bat (Rhinolophus lobatus Peters) in Radford is better to be revised as Miniopterus natalensis arenarius Heller. In passing, the bats of the genus Rhinolophus are specific hosts of the mites of the genus Neomyobia, and Radford (1940) also described a Neomyobia under the name of Myobia jacksoni in the same paper.

The specimens of $C$. rhinolophia taken in the present study are listed in Table 1.

Table 1 Records of Calcarmyobia rhinolophia (Radford)

\begin{tabular}{|c|c|c|c|c|}
\hline Codes No. Mites & $\begin{array}{l}\text { BMNH } \\
\text { Accession } \\
\text { Number }\end{array}$ & Host & Locality & Host Accession Number \\
\hline \#79 19 & & Miniopterus sp. & Sudan & USNM 252716 \\
\hline \#3 1రิ1우 & & M. fuscus fraterculus & Natal, S. Africa & AMNH 245207 \\
\hline \#61 1ठ3ㅇ & 1984.6.12.1-3 & $M$. inflatus africanus & Kenya & BMNH 75.898-906 \\
\hline \#45 2రితే1N & & M. natalensis arenarius & Mt Elgon, Kenya & FMNH 67958-65 \\
\hline \#46 2ठేరి3 & & M. natalensis arenarius & Mt Menengai, Kenya & FMNH 85467-78 \\
\hline$\# 422 \delta 0 َ 50+71 \mathrm{~N}$ & $1984.6 .12 .4-9$ & M. natalensis arenarius & Mt Elgon, Kenya & BMNH 36.3.16.13-20 \\
\hline \#44 1 万2 290 & $1984.6 .12 .10-11$ & M. natalensis arenarius & Kapretwa, Mt Elgon & BMNH 1938.5.10.10-14* \\
\hline \#451 & $1984.6 .12 .12-13$ & M. natalensis arenarius & Kapretwa, Mt Elgon & BMNH $40.726-37^{*}$ \\
\hline \#65 20ㅇำ요 & & M. schreibersi & S. Sudan & FMNH 108169-70 \\
\hline$\# 412 \delta \widehat{\sigma} 2+q 1 \mathrm{~N}$ & & M. schreibersi arenarius & Mt Menengai, Kenya & FMNH 91619-706 \\
\hline \#36 1б1우 & 1984.6.12.14-15 & M. schreibersi arenarius & Kenya & BMNH 70.726 \\
\hline$\# 412 \delta 013092 \mathrm{~N}$ & $1984.6 .12 .16-24$ & M. schreibersi arenarius & Mt Elgon, Uganda & BMNH 73.527-30 \\
\hline \#47 16 & & M. schreibersi arenarius & Kenya & SMF 39425 \\
\hline$\# 4619$ & 1984.6.12.25 & M. schreibersi natalensis & Rhodesia & BMNH 54.1045 \\
\hline \#3 1 ô1ㅇํ $1 \mathrm{~N}$ & & M. schreibersi natalensis & Zambia & AMNH 89780-3 \\
\hline
\end{tabular}

*Specimens collected by Hopkins and Jackson.

Table 2 Records of Calcarmyobia miniopteris (Womersley)

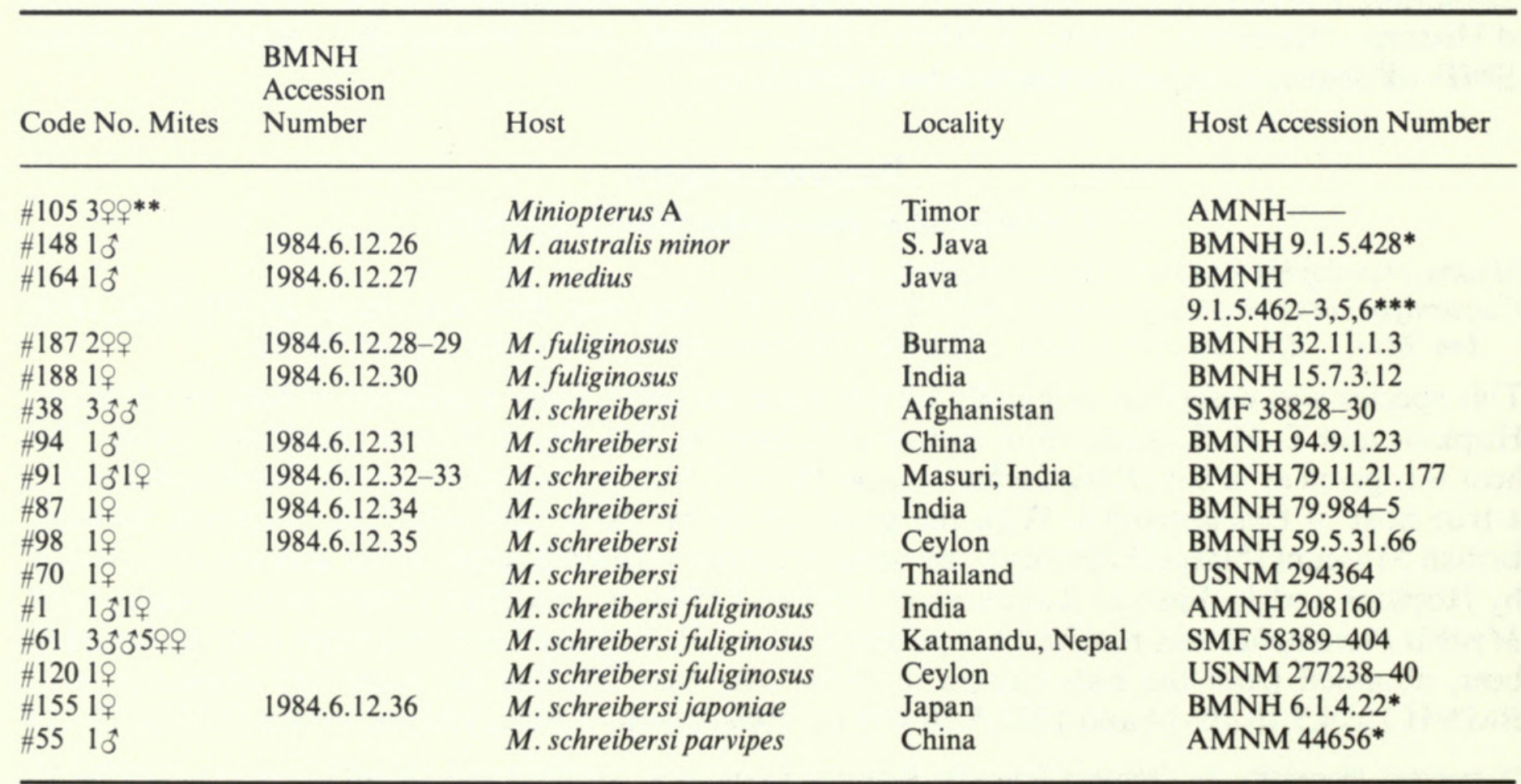

*Type specimen, ${ }^{* *}$ Tentatively identified, ${ }^{* * *}$ Specimens with the same data as those of the type of $M$. medius (BMNH 9.1.5.4624) yielded also 2 other species of Calcarmyobia. 
Calcarmyobia miniopteris (Womersley, 1941)

Myobia miniopteris Womersley, 1941, Rec. S. Aust. Mus., 7: 52.

Calcarmyobia rhinolophia (Radford, 1940), Radford, 1952, Bull. Mus. Hist. Nat., Paris, $24,371$.

Calcarmyobia japonica Uchikawa, 1976, Annot. zool. Japon., 4: 56.

Calcarmyobia miniopteris (Womersley, 1941), Fain \& Lukoschus, 1979, Rec. West Aust. Mus., 7: 72.

Calcarmyobia miniopteris (Womersley) was once synonymized with C. rhinolopia (Radford), but its validity was proved in 1976 by the present author, though he dealt with it as a new species. The specimens taken in the present study are shown in Table 2 and in the distribution map, Fig. 9. A male taken from the type of $M$. australis minor that has been synonymized with $M$. paululus by Maeda (1982) is thought to be a stray specimen. This will be mentioned again in the next paper.

\section{Calcarmyobia congoensis Uchikawa, 1982}

Calcarmyobia congoensis Uchikawa, 1982, Annot. zool. Japon., 55: 36.

Calcarmyobia rhinolophia (Radford, 1940), Lawrence, 1951, Ann. Natal. Mus., 12: 103.

Myobia miniopterus Womersley, 1941, Lavoipierre, 1946, J. Entomol. Soc. S. Afr., 9: 78.

Calcarmyobia congoensis Uchikawa was described from 4 male and 2 female specimens from Miniopterus, which were not satisfactorily identified (Ukchikawa, 1982). This species is closely allied to C. rhinolophia (Radford). The males of both species are, however, easily separable from each other by the structure of the genital shield and by the nature of $g p$ on the shield. Compared with the inflated $g p$ of $C$. rhinolophia, the seta is fine and setiform on the type specimens of C. congoensis.

In the present study are some 90 male specimens of the mites, which have the genital shield essentially the same in structure to that of the type specimens of $C$. congoensis. All the above specimens and their partner females have been identified as $C$. congoensis, but the particular seta $g p$ shows a remarkable variation in thickness. The seta is typically setiform as in Fig. 1a on some specimens, but is obviously thickened as in Figs $1 \mathrm{~b}$ and $1 \mathrm{c}$ on others. Contrary to such the clear differences in the males, the partner females of both the forms are barely separable by the nature of some setae. The striated basal part of setae $d_{1}$ and $d_{4}$ is slightly shorter on the partner females of the typical males than on those of the atypical males, and, thus, the outline of that part is
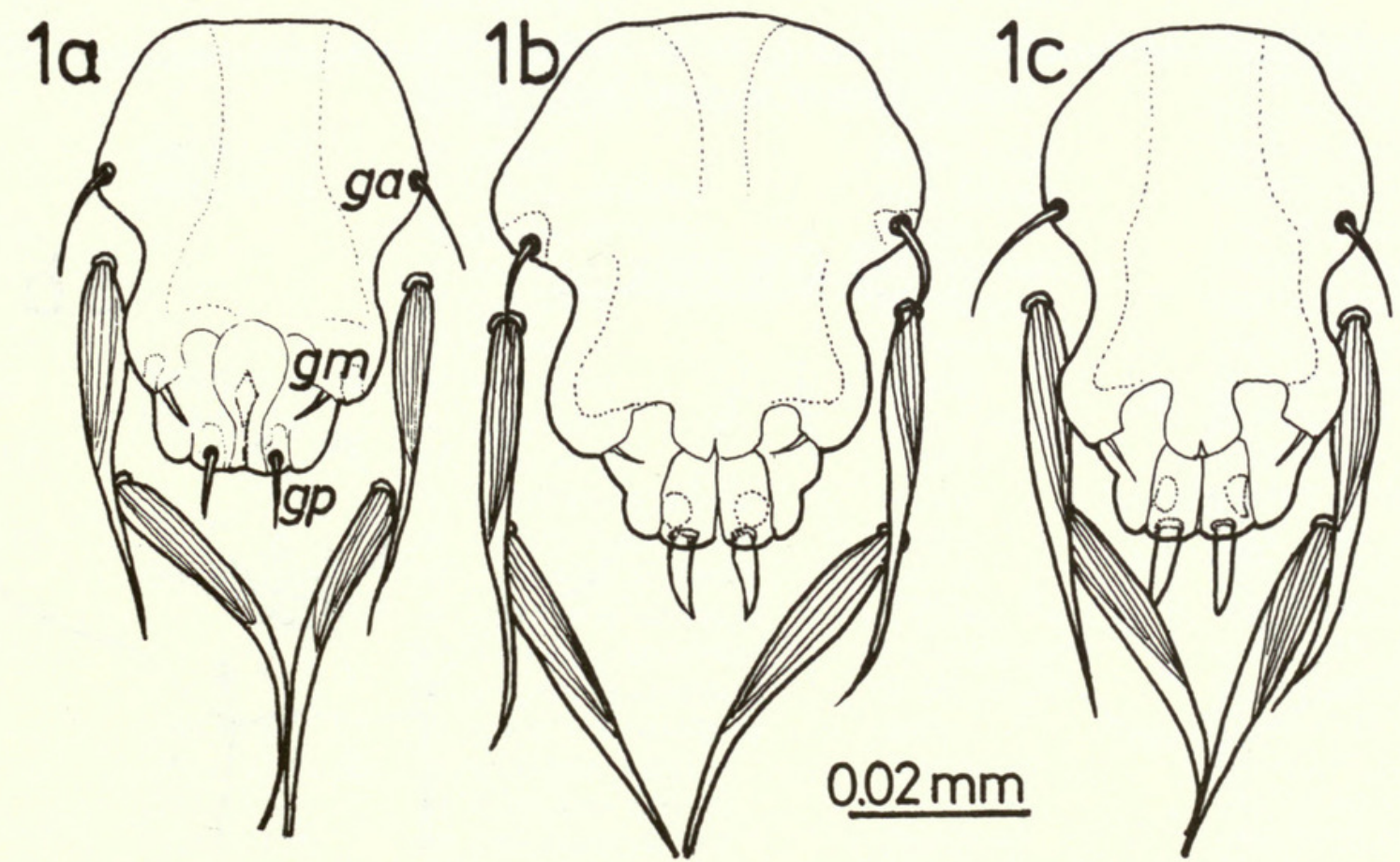

Fig. 1 Variation in thickness of the setae $g p$ on the male of Calcarmyobia congoensis Uchikawa: typical (1a); atypical (1b \& c) forms. 


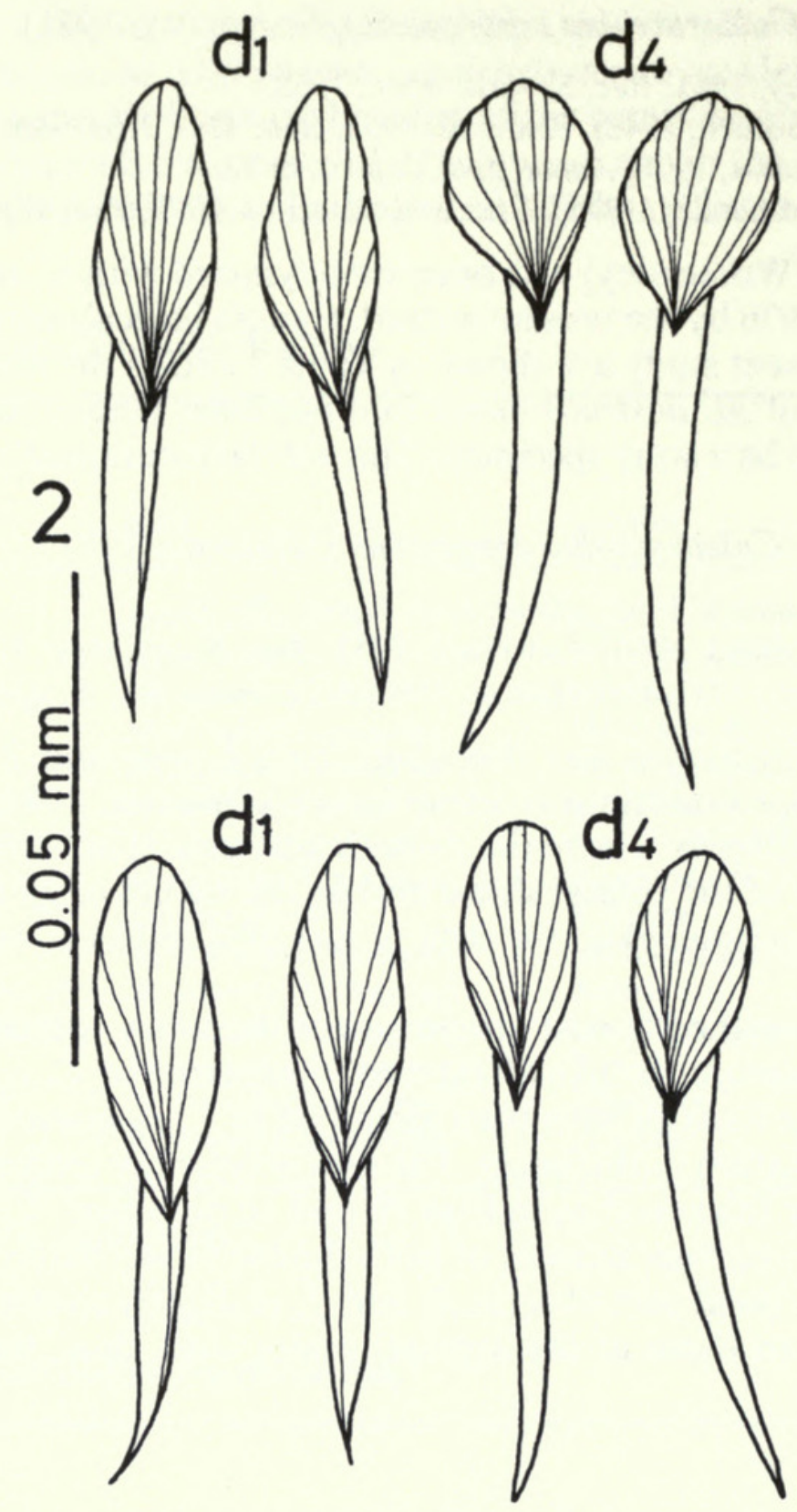

Fig. 2 Differences in the dorsal setae, $d_{1}$ and $d_{4}$, on the female of Calcarmyobia congoensis Uchikawa: typical (upper); atypical (lower) forms.

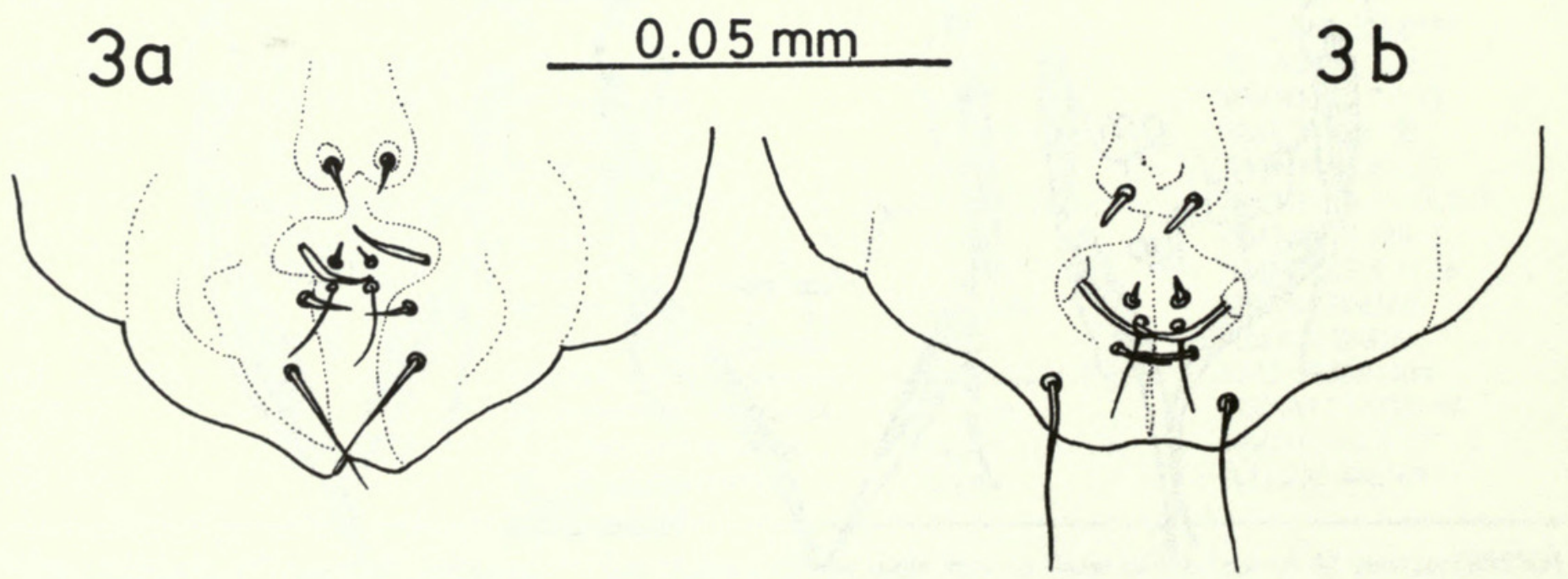

Fig. 3 Difference in the internal anal setae, ai, on the female of Calcarmyobia congoensis Uchikawa: typical (3a); atypical (3b) forms. 
somewhat different in the two forms as depicted in Fig. 2. The anal seta $a i$ is usually less prominent on the typical form than on the atypical form as shown in Fig. 3. According to these subtle differences in both sexes, the two forms of $C$. congoensis taken in the present study are recorded separately in Tables 3 and 4 . Although both forms of the mites are regarded as being conspecific in the present study, the host and locality records in Tables 3 and 4 may be useful in consideration of the distribution pattern of the host bats and in their phylogenetic relationships.

Calcarmyobia congoensis seems to be prevailing in the Ethiopian region excluding the western part, where data are still wanting, and in Madagascar (Fig. 9). The typical form was taken frequently from the bats from the central to western parts of Africa, and the atypical form from those from Ethiopia to South Africa and just into eastern Africa. There was, however, no strict geographical segregation in the distribution of both the forms. As to the host bats, the type host of C. congoensis, Miniopterus from Congo (MNHN 25-05-69) is not yet properly identified. Among the host bats of the typical form in Table 2, only M. villiersi seems to be one of the true hosts of the mite. Some other host bats are still anonymous or to be reconfirmed as discussed later. On the other hand, the type specimens of $M$. africanus, M. breyeri, $M$. dasythrix and $M$. scotinus harboured the atypical form of $C$. congoensis and these species are regarded as the true hosts of the mite with the additional data in Table 3. Miniopterus natalensis and M. smitianus are also thought to be the true hosts of the atypical form of $C$. congoensis.

Lavoipierre (1946) and Lawrence (1951) recorded Myobia miniopterus Womersley and $C$. rhinolophia (Radford), respectively, from M. natalensis in Transvaal and Natal, South Africa. Their mites have not been re-examined referring to the present knowledge of Calcarmyobia, but it

Table 3 Records of Calcarmyobia congoensis Uchikawa, typical form

\begin{tabular}{|c|c|c|c|c|}
\hline Code No. Mites & $\begin{array}{l}\text { BMNH } \\
\text { Accession } \\
\text { Number }\end{array}$ & Host & Locality & Host Accession Number \\
\hline \#79 19 & & Miniopterus sp. & Sudan & USNM 252716 \\
\hline \#16 19 & & Miniopterus sp. & Central Africa & MNHN - \\
\hline 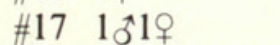 & & Miniopterus sp. & Central Africa & MNHN - \\
\hline \#18 1 1ठ2qq & & Miniopterus sp. & Central Africa & MNHN - \\
\hline 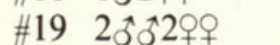 & & Miniopterus sp. & Central Africa & $\mathrm{MNHN}-$ \\
\hline 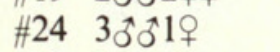 & & Miniopterus sp. & Cameroun & MNHN - \\
\hline \#39 $132+9$ & & Miniopterus sp. & Angola & FMNH 84125-37 \\
\hline \#62 1\$10 & & M. fraterculus & Angola & FMNH 83601 \\
\hline$\# 66 \quad 10^{\circ}$ & 1984.6.12.37 & M. inflatus & Belg. Congo & BMNH 59.512 \\
\hline$+6210^{\star}$ & 1984.6 .12 .38 & M. inflatus africanus & Belg. Congo & BMNH 59.513-5 \\
\hline 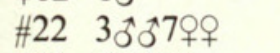 & & M. inflatus africanus & Kenya & USNM 351059 \\
\hline$\# 34 \quad 60^{2} 4+9$ & & M. natalensis & Mozambique & USNAM 365448-52 \\
\hline$\# 33 \quad 10^{*}$ & & M. natalensis & Rhodesia & USNM 368613-4 \\
\hline \#63 19 & & M. natalensis & Rhodesia & USNM 95156-7 \\
\hline \#1731 1 32 2우 & $1984.6 .12 .39-41$ & M. schreibersi & Angola & BMNH 4.4.9.25-6 \\
\hline$\# 17519$ & 1984.6.12.42 & M. schreibersi & Belg. Congo & BMNH 95.7.16.2 \\
\hline 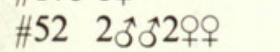 & & M. schreibersi & Zambia & SMF 48029-37 \\
\hline \#49 2q9 & & M. schreibersi arenarius & Sudan & FMNH 68106-8 \\
\hline \#55 11 ठ2 2 \% & & M. schreibersi arenarius & Kenya & SMF 19862-3 \\
\hline \#16919 & 1984.6.12.43 & M. schreibersi arenarius & Kenya & BMNH 10.4.1.27 \\
\hline 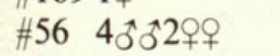 & & M. schreibersi natalensis & Katanga, Zaire & SMF $21300-9$ \\
\hline 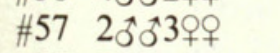 & & M. schreibersi natalensis & Katanga, Zaire & SMF $19072-8$ \\
\hline$\# 47 \quad 290$ & & M. schreibersi natalensis & N. Rhodesia & FMNH $96270-1$ \\
\hline$\# 55 \quad 1 \sigma^{\circ}$ & 1984.6.12.44 & M. schreibersi natalensis & Zaire & BMNH $74.512-6$ \\
\hline \#84 4우 & 1984.6.12.45-48 & M. schreibersi villiersi & Cameroun & BMNH 68.647 \\
\hline$\# 85 \quad 2 \hat{\sigma} \sigma^{\circ}$ & 1984.6.12.49 & M. schreibersi villiersi & Cameroun & BMNH $68.330-1$ \\
\hline$\# 16519$ & 1984.6 .12 .50 & M. schreibersi villiersi & Cameroun & BMNH $60.106-7$ \\
\hline \#66 $1 \delta^{\star} 33$ 우 & & M. schreibersi villiersi & Cameroun & FMNH 42587-90 \\
\hline$\# 10 \quad 10^{\$} 2 \%+9$ & & M. schreibersi villiersi & ? & AMNH 49321 \\
\hline
\end{tabular}


is highly probable that they had dealt with the same species of mite. The mite is thought not to be other than the atypical form of $C$. congoensis from Tables 3 and 4.

\section{Calcarmyobia dusbabeki nom. nov.}

Calcarmyobia rhinolophia (Radford, 1940), Dusbábek, 1963, Acta. Soc. ent. Céchoslov., 60: 248; Uchikawa, 1976, Annot. zool. Japon., 49: 57; Fain \& Aellen, 1979, Rev. suisse Zool., 86: 218.

?Calcarmyobia parenzani Lombardini, 1956, Fain \& Aellen, 1979, Rev. suisse Zool., 86: 218; Fain \& Lukoschus 1979, Rec. West Aust. Mus., 7: 70: Uchikawa, 1982, Annot. zool Japon., 55: 35.

Table 4 Records of Calcarmyobia congoensis Uchikawa, atypical form

\begin{tabular}{|c|c|c|c|c|}
\hline Code No. Mites & $\begin{array}{l}\text { BMNH } \\
\text { Accession } \\
\text { Number }\end{array}$ & Host & Locality & Host Accession Number \\
\hline$\# 80 \quad 10^{*}$ & & Miniopterus sp. & Rhodesia & USNM 154587 \\
\hline \#83 $1 \delta^{\star} 2$ 2우 & & Miniopterus sp. & Transvaal & USNM $237550-4$ \\
\hline$\# 612 \sigma^{\circ} \sigma^{7} 2+93 \mathrm{~N}$ & & M. africanus & Ethiopia & $\begin{array}{l}\text { FMNH } \\
28765,-7-8,770^{*}\end{array}$ \\
\hline$\# 18510^{\circ}$ & 1984.6.12.51 & M. africanus & Big Abbai & BMNH 28.1.11.29-30 \\
\hline$\# 1821330 \%$ & $1984.6 .12 .52-55$ & M. breyeri & Transvaal & BMNH 9.7.2.3-5,7-8 \\
\hline \#15019 & 1984.6 .12 .56 & M. breyeri & Transvaal & BMNH 9.7.2.6* \\
\hline 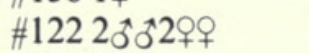 & & M. breyeri vicinior & Aba, Zaire & AMNH $49021,-25$ \\
\hline$\# 2 \quad 2$ 2 & & $M$. breyeri vicinior & Aba, Zaire & AMNH 49031 \\
\hline 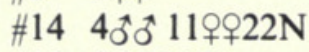 & & M. dasythrix & Caffrérie, S. Africa & RMNH 25093* \\
\hline \#18 200 వ2ㅇำ & & M. fraterculus & Transvaal & USNM 342641 \\
\hline \#19 $1 \delta^{\star} 29+9$ & & M. fraterculus & S. Africa & USNM $381629,-32-4$ \\
\hline \#6 4우우 & & M. fuscus fraterculus & Mozambique & AMNH 216228 \\
\hline \#44 1 10ึ1우 & & M. inflatus & Kenya & SMF 43660 \\
\hline \#63 30ิరి & 1984.6.12.57-59 & M. inflatus africanus & Ethiopia & BMNH 70.492 \\
\hline$\# 65 \quad 209$ & 1984.6 .12 .60 & M. inflatus africanus & Ethiopia & BMNH $72.246-87$ \\
\hline \#71 $1 \delta^{52}+9$ & 1984.6.12.61-63 & M. inflatus africanus & Ethiopia & BMNH 71.606-15 \\
\hline \#24 $1 \delta^{32} 29+9$ & & M. inflatus africanus & Kenya & USNM 436816-35 \\
\hline$\# 4 \quad 1 \delta 19$ & & M. minor fraterculus & S. Africa & AMNH 116091 \\
\hline$\# 47 \quad 10^{\circ}$ & 1984.6.12.64 & M. natalensis & Transvaal & BMNH 49.722 \\
\hline 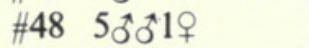 & 1984.6.12.65-70 & M. natalensis & S. Africa & BMNH 52.1364-74 \\
\hline$\# 51 \quad 19$ & 1984.6.12.71 & M. natalensis & Rhodesia & BMNH $62.2099-100$ \\
\hline \#53 10े & 1984.6.12.72 & M. natalensis & Transvaal & BMNH $51.729-32$ \\
\hline \#54 1ठ1ㅇ & 1984.6 .12 .73 & M. natalensis & Natal & BMNH 51.21-6 \\
\hline \#11919 & & M. natalensis & Natal & AMNH 245208 \\
\hline \#1523우 & & M. natalensis & Transvaal & BSPM $145607-8$ \\
\hline \#62 19 & & M. natalensis & Kenya & USNM $317129-28$ \\
\hline$\# 67 \quad 1 \sigma^{*}$ & & M. natalensis & Kenya & USNM 166591,-93 \\
\hline \#92 $2 \delta^{\circ} 6{ }^{3} 60 q$ & 1984.6.12.74-81 & M. schreibersi & Transvaal & BMNH 9.7.2.27-8 \\
\hline \#65 40ే & & M. schreibersi & S. Africa & USNM 479536-7 \\
\hline \#40 396+ & $1984.6 .12 .82-83$ & M. schreibersi arenarius & Ethiopia & BMNH $72.4447-8$ \\
\hline$\# 46 \quad 1 \sigma^{\circ}$ & & M. schreibersi arenarius & Ethiopia & SMF 45735 \\
\hline \#31 1 1ర1웅 & & M. schreibersi arenarius & Kenya & FMNH 182697 \\
\hline \#36 19 & & M. schreibersi natalensis & Transvaal & USNM 156337 \\
\hline \#37 $1 \delta^{\star} 29+9$ & & M. schreibersi natalensis & Transvaal & USNM $221423-30$ \\
\hline \#21 $20^{0} \sigma^{7} 8$ 우 & & M. schreibersi natalensis & Botswana & RMNH 30694 \\
\hline \#23 3రేరె7우 & & M. schreibersi natalensis & Botswana & RMNH 30693 \\
\hline$\# 382 \sigma^{\circ}$ & & M. schreibersi natalensis & S. Africa & USNM 376762 \\
\hline$\# 40 \quad 19$ & & M. schreibersi natalensis & S. Africa & USNM 381599-606 \\
\hline$\# 58 \quad 10^{*}$ & & M. schreibersi natalensis & Transvaal & SMF 44807 \\
\hline \#151 19 & 1984.6.12.84 & M. scotinus & Caffraria, S. Africa & BMNH 46.6.2.19* \\
\hline \#174 299 & 1984.6 .85 & M. scotinus & Salisburg, Rhodesia & BMNH 95.7.16.1-2 \\
\hline$\# 1711 \delta^{*} 19$ & $1984.6 .12 .86-87$ & M. smitianus & S. W. Africa & BMNH 35.1.6.41-2 \\
\hline \#172 1ర2우우 & 1984.6.12.88-90 & M. smitianus & S. W. Africa & BMNH 35.9.1.83 \\
\hline
\end{tabular}

*Type specimen(s). 
The mite of the genus Calcarmyobia found in Europe was first identified as C. rhinolophia (Radford) by Dusbábek (1963), and, then, was proved to be a species distinctly different from the Japanese form, based on the definite criteria for differentiating species of Calcarmyobia (Uchikawa, 1976). Fain \& Lukoschus (1979) suggested that C. parenzani, inadequately described by Lombardini (1956), might probably become valid as representing the populations parasitizing $M$. schreibersi in Europe. Uchikawa (1982) once followed them, but is now of the opinion that $C$. parenzani Lombardini does not represent the genus Calcarmyobia, and that the mite should be named on the designation of the type specimens (Uchikawa, 1984). In the present study, the specimens were found on the bats from Romania, the type locality of $M$. schreibersi. A brief description of $C$. dusbabeki nom. nov. is given below based on these specimens as the types.
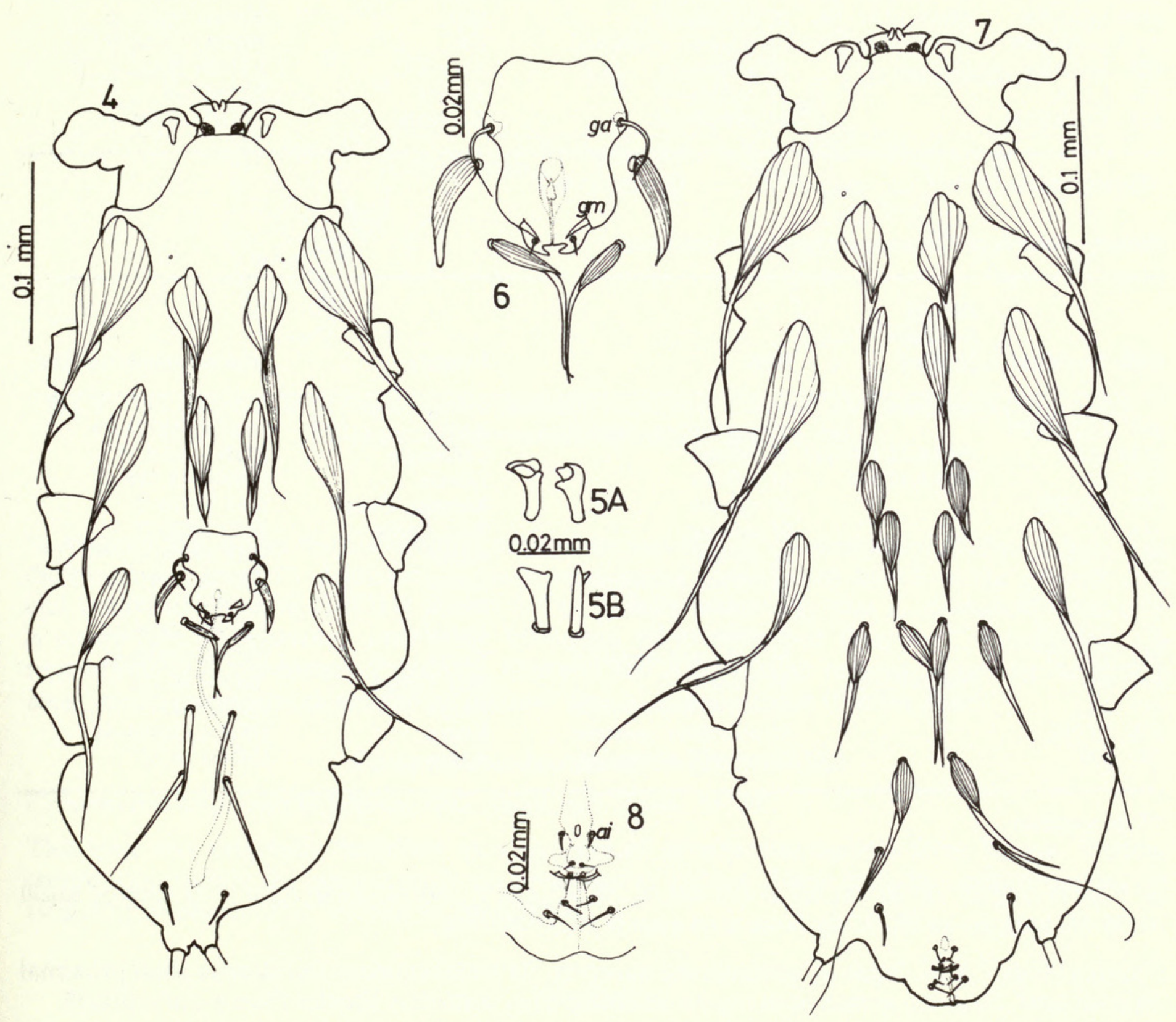

Figs 4-8 Calcarmyobia dusbabeki nom. nov.: male dorsum (4); modified claw on leg II (5a); modified seta on tibia II (5b); genital shield and setae $d_{1}$ and $d_{2}$ (6); female dorsum (7); genito-anal setae (8).

MaLE (Figs 4, $5 \&$ 6). Setae $v i$ tapering; $d_{1}$ flattened. Genital shield bearing spiniform $g m$, which are situated close to terminal lobes; genital pore slightly anterior to level of gm. Modified claw on leg II and modified seta, $a l$, on genu II as in Fig. 5. A ventral seta on tarsus II long and thick.

Measurements in $\mu \mathrm{m}$ for holotype and, in parentheses, for two paratypes. Body (gnathosoma+ idiosoma) 470 (470-490) long by 210 (215-220) wide. Setae ve 145 (140-133); vi 138 (?-140); sc e ?(160-165); 
Table 5 Records of Calcarmyobia dusbabeki nom. nov.

\begin{tabular}{|c|c|c|c|c|}
\hline Code No. Mites & $\begin{array}{l}\text { BMNH } \\
\text { Accession } \\
\text { Number }\end{array}$ & Host & Locality & Host Accession Number \\
\hline 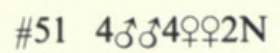 & & M. schreibersi & Afghanistan & FMNH 110911-3 \\
\hline \#11 5우요 & & M. schreibersi & Ukraina, USSR & AMNH 244266 \\
\hline 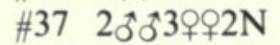 & & M. schreibersi & Afghanistan & SMF 38835-9 \\
\hline \#53 1 1ठ19 & & M. schreibersi & Tunisia & SMF 22221-31 \\
\hline \#88 3우우 & 1984.6.12.91-93 & M. schreibersi & Tunisia & BMNH 79.918-24 \\
\hline$\# 10119$ & 1984.6.12.94 & M. schreibersi & Syria & BMNH 46.247 \\
\hline \#1034우우 & 1984.6.12.95-96 & M. schreibersi & Iran & BMNH $14.39-41$ \\
\hline \#105 1ठ33우1N & 1984.6.12.97-100 & M. schreibersi & Iran & BMNH $14.26-38$ \\
\hline \#145 1 1 $7790936 \mathrm{~N}$ & 1984.6.12.101-109 & M. schreibersi pallidus & Iran & BMNH 7.7.14.7* \\
\hline \#28 2రิธ33우요 & & M. schreibersi & Algeria & RMNH 28528 \\
\hline$\# 16 \quad 131 \mathrm{~N}$ & & M. schreibersi & Algeria & RMNH - \\
\hline 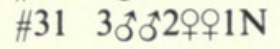 & & M. schreibersi & Rumania & RMNH 28708-14 \\
\hline
\end{tabular}

*Type specimen.

Table 6 Records of Calcarmyobia kenyaensis Uchikawa

\begin{tabular}{|c|c|c|c|c|}
\hline Code No. Mites & $\begin{array}{l}\text { BMNH } \\
\text { Accession } \\
\text { Number }\end{array}$ & Host & Locality & Host Accession Number \\
\hline 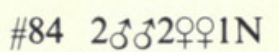 & & Miniopterus sp. (2spp.?) & Kenya & USNM 351247-59 \\
\hline$\# 1541 \Omega^{32 N}$ & 1984.6.12.110-111 & M. inflatus & Cameroun & BMNH 3.2.4.8* \\
\hline$\# 70 \quad 10^{\circ}$ & 1984.6 .12 .112 & M. inflatus & Liberia & BMNH 79.520 \\
\hline 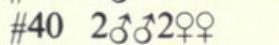 & & M. inflatus & Katanga, Congo & SMF $21310-2$ \\
\hline$\# 4119$ & & M. inflatus & Belg. Congo & SMF 18926-7 \\
\hline \#42 1 1ठ29+9 & & M. inflatus & Kenya & SMF 39423-4 \\
\hline \#17 290 & & M. inflatus africanus & Kenya & USNM $351014-5$ \\
\hline$\# 233 \delta^{0} \sigma^{*} 1$ + $1 \mathrm{~N}$ & & M. inflatus africanus & Kenya & USNM 351040-1 \\
\hline 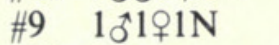 & & M. inflatus rufus & Uganda & AMNH $184358-9$ \\
\hline$\# 45 \quad 10^{\circ}$ & & M. natalensis arenarius & Kenya & FMNH 67958-65 \\
\hline \#97 $1 \sigma^{\circ}$ & 1984.6.12.113 & M. schreibersi & Belg. Congo & BMNH 60.112 \\
\hline$\# 47 \quad 2 \sigma^{0} 0^{\circ}$ & & M. schreibersi arenarius & Kenya & SMF 39425 \\
\hline 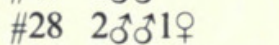 & & M. schreibersi arenarius & Kenya & USNM 436845-58 \\
\hline \#31 3우 & & M. schreibersi arenarius & Kenya & USNM 182697 \\
\hline
\end{tabular}

*Type specimen.

sc $i 73$ (75-77); $d_{1} 35$ (30-35); $d_{2} 45$ (43-44); $d_{3} 50$ (43-45); $l_{1} 160(165-165) ; l_{3} 70$ (?-?). Genital shield 53(50-53) long; ga-ga 37(37-38). Setae al on genu II 18(18-20) long.

Female (Figs $7 \& 8$ ). Setae $d_{1}$ terminating abruptly; its membraneous tail shorter than proximal striated part. Setae on genito-anal region as in Fig. 8; $g_{5}$ distinctly shorter than $g_{7}$; ai setiform.

Measurements in $\mu \mathrm{m}$ for allotype and a paratype. Body 590-605 long by 270-260 wide. Setae ve $168-165 ;$ vi $105-105 ;$ sc e $188-190 ;$ sc $i 108-107 ; d_{1} 53-38 ; d_{2} 63-78 ; d_{3} 90-95 ; d_{4} 90-98 ; l_{1} 200-202 ; l_{2} 85-90$; $d_{1}-d_{1} 50-50 ; d_{2}-d_{2} 30-30 ; d_{3}-d_{3} 22-23 ; l_{2}-l_{2} 70-73$.

TyPES. Holotype male, allotype female, 2 paratype males and a paratype female ex Miniopterus schreibersi, cave near Tirgussor, Romania, 24-May-1971 (RMNH 28708-14). The types are deposited in the collection of RMNH.

The other specimens of $C$. dusbabeki nom. nov. examined in the present study are listed in Table 5. This mite was found only on $M$. schreibersi from the circum-Mediterranean regions east 


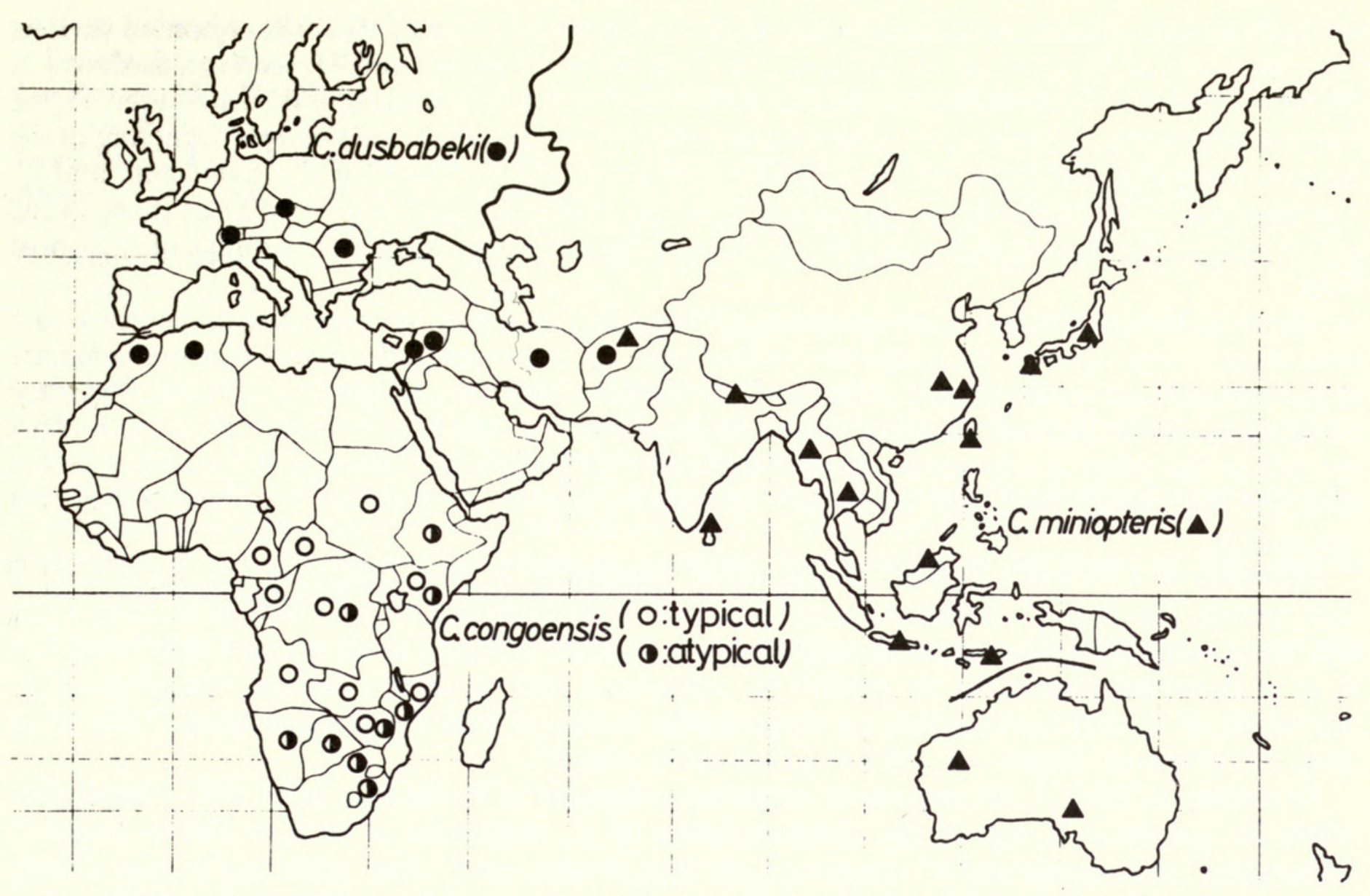

Fig. 9 The distribution of Calcarmyobia dusbabeki nom. nov., Calcarm.'obia miniopteris (Womersley, 1941) and Calcarmyobia congoensis Uchikawa, 1982.

to Afghanistan, where the distribution of the mite met that of C. miniopteris (Tables $2 \& 5$ ). The distribution map of $C$. dusbabeki, C. congoensis and C. miniopteris based on the present data and those in Uchikawa (1983) is shown in Fig. 9. It is noteworthy that C. dusbabeki nom. nov. is closer to $C$. congonensis and other Ethiopian mites described than to $C$. miniopteris, the representative in the eastern Palearctic, Oriental and Australasian regions, in having the genital setae $g m$ on the genital shield and an inflated ventral seta on tarsus II in the male.

\section{Calcarmyobia kenyaensis Uchikawa, 1982}

Calcarmyobia kenyaensis Uchikawa, 1982, Annot. zool. Japon., 55: 37.

This mite was originally described as a parasite of Miniopterus inflatus from Kenya. Further records obtained in the present study are presented in Table 6 . These include a male found on the type skin specimen of $M$. inflatus in the BMNH.

\section{Discussion}

The solutions to the three problems concerning the known species of the genus Calcarmyobia (Uchikawa, 1984) have been obtained in the present study. The first is that the host of $C$. rhinolophia, the generic type, is presumed to be Miniopterus natalensis arenarius. The second is that records of Myobia miniopterus and C. rhinolophia from M. natalensis in South Africa (Lavoipierre, 1946; Lawrence, 1951) are now thought to be the atypical form of C.congoensis. Finally, the well known but unnamed Calcarmyobia distributed in Europe has been described and type specimens designated.

The geographical distribution of some mites of the genus Calcarmyobia has been further established with accumulation of the data in the present study. Calcarmyobia congoensis with a 
remarkable intraspecific variation prevails in almost the whole of the Ethiopian region on various bats, inclusive of the types of $M$. africanus, $M$. breyeri, $M$. dasythrix and $M$. scotinus, as shown in Tables 3 and 4. Calcarmyobia dusbabeki nom. nov. is, on the other hand, distributed in the western Palearctic region east to Afghanistan, where it meets with C. miniopteris occurring in the eastern Palearctic, Oriental and Australasian regions (Fig. 9). Data for C. rhinolophia and $C$. kenyaensis are still fragmentary, yet ranges for these mites seem not to be so wide as those of the above species. Such limited distribution pattern of the mites may suggest groupings of their host bats.

The host bats of the five mite species considered in this paper are recorded in Tables 1 to 6 according to the labels in the respective collections. As the mites of the genus Calcarmyobia are oligoxenic and not synhospitalic (Uchikawa \& Harada, 1981), it is likely for a mite to parasitize all subspecies of a bat, and for a host bat to harbour only a single species of the mites. Many host records in the tables are, however, against this rule. The present author expects that information deduced exclusively from the mites will draw attention to contradictory points in the host taxonomy.

Miniopterus schreibersi appears in all tables, suggesting a most unsatisfactory definition of this species. The mite $C$. dusbabeki parasitic on $M$. schreibersi in Europe, the type locality of the bat, has a rather limited range only in the western Palearctic region as shown in Table 5 and Fig. 9. It is therefore reasonable to regard $M$. schreibersi and its close relatives, the hosts of $C$. dusbabeki, as the bats distributed in a range similar to that of their common parasite. If this is the case, schreibersi in Tables $1-4$ and 6 will need to be revised.

As shown in Table 1, M. natalensis arenarius is thought to be the true holst of $C$. rhinolophia, while $M$. natalensis is one of the common hosts of $C$. congoensis as seen in Tables 3 and 4 . Although $C$. rhinolophia and $C$. congoensis are very close to each other, reflecting a close affinity among their hosts, it is improbable that different subspecies of a bat would harbour specific mites of the genus Calcarmyobia. Thus, arenarius originally described as a subspecies of M. natalensis should be elevated to a full species or be transferred to a subspecies of a species other than $M$. natalensis.

$M$. africanus, the paratypes of which yielded the atypical form of $C$. congoensis, is sometimes ranked as a subspecies of $M$. inflatus (Tables $3 \& 4$ ). As the type and other specimens of $M$. inflatus frequently harboured $C$. kenyaensis (Table 6), M. inflatus is believed to be a true host of $C$. kenyaensis, and, then, the host of $C$. congoensis should not be treated as a subspecies of the host bat of $C$. kenyaensis.

All six tables contain host records that are contradictory to our main premise. Some mites might have been transferred to the wrong hosts before the present author examined them, and, in some cases, misidentification might have been made for some bats even in the collections of the leading museums.

\section{Acknowledgements}

Gratitude is expressed to the curators and other staffs of the Mammal Sections of all the Museums listed above for allowing the author to examine the bats deposited in their collections for ectoparasites. Thanks are also due to Mr John Edwards Hill, Mammal Section, British Museum (Natural History), for pertinent suggestions on the bats collected by G. H. E. Hopkins and T. H. E. Jackson and Mr K. H. Hyatt for critical reading of the manuscript.

\section{References}

Dusbábek, F. 1963. Parasitische Fledermausmilben der Tschechoslowakei. III. Fam. Myobiidae (Acarina, Trombidiformes). Acta. Soc. ent. Céchoslov. 60: 231-251.

Fain, A. 1978. Les Myobiidae d'Afrique au sud du Sahara et de Madagascar (Acarina, Prostigmata). Ann. Mus. r. Afr. Cent., Sci. zool. 224: 1-186.

— \& Aellen, V. 1979. Les Myobiidae (Acarina, Prostigmata) parasites des chauves-souris de Suisse. I. Revue suisse Zool. 86: 203-220. 
\& Lukoschus, F. 1979. Parasites of western Australia. VI. Myobiidae parasitic on bats (Acarina: Prostigmata). Rec. West. Aust. Mus. 7: 61-107.

Lavoipierre, M. 1946. New records of Acari from Southern Africa and the Belgian Congo. J. Entomol. Soc. S. Afr. 9: 78-81.

Lawrence, R. F. 1951. New fur-mites from South African mammals. Ann. Natal Mus. 12: 91-133.

Radford, C. D. 1940. Notes on some new species of parasitic mites. Part 3. Parasitol. 32: 91-104. 1952. A revision of the fur mites Myobiidae (Acarina) (Suite). Bull. Mus. Hist. Nat., Paris 24: 371-381.

Uchikawa, K. 1976. Myobiid mites (Acarina, Myobiidae) parasitic on bats in Japan. I. Genus Calcarmyobia Radford, 1952. Annot. zool. Japon. 49: 55-59.

1982. Mites of the genera Calcarmyobia and Pteracarus (Trombidiformes, Myobiidae) parasitic on Miniopterus (Chiroptera). Ibid. 55: 32-45.

1984. Revision of the genus Calcarmyobia Radford (Trombidiformes, Myobiidae) and application of the mites to the systematics of their hosts (Chiroptera), In Griffiths, D. A. \& Bowman, C. E., (Eds.) Acarology VI, Vol. 1, pp. 196-201. Ellis Harwood, Chichester.

\& Harada, M. 1981. Evaluation of bat-infesting Myobiidae (Acarina, Trombidiformes) as indicators in taxonomy and phylogeny of host bats (Chiroptera). Zoo. Mag. 90: 351-361.

Womersley, H. 1941. Notes on the Cheyletidae (Acarina, Trombidoidea) of Australia and New Zealand with descriptions of new species. Rec. Austral. Mus. 7: 51-64.

Manuscript accepted for publication 4 July 1984 


\section{$2 \mathrm{BHL}$ Biodiversity Heritage Library}

Uchikawa, Kimito. 1985. "Mites of the genus Calcarmyobia (Acarina, Myobiidae) with information on the taxonomy of their host bats of the genus Miniopterus (Chiroptera, Miniopteridae)." Bulletin of the British Museum (Natural History) Zoology 48, 15-25. https://doi.org/10.5962/bhl.part.23459.

View This Item Online: https://www.biodiversitylibrary.org/item/19651

DOI: https://doi.org/10.5962/bhl.part.23459

Permalink: https://www.biodiversitylibrary.org/partpdf/23459

\section{Holding Institution}

Natural History Museum Library, London

\section{Sponsored by}

Natural History Museum Library, London

\section{Copyright \& Reuse}

Copyright Status: In copyright. Digitized with the permission of the rights holder.

Rights Holder: The Trustees of the Natural History Museum, London

License: http://creativecommons.org/licenses/by-nc-sa/4.0/

Rights: http://biodiversitylibrary.org/permissions

This document was created from content at the Biodiversity Heritage Library, the world's largest open access digital library for biodiversity literature and archives. Visit BHL at https://www.biodiversitylibrary.org. 